\title{
PENGARUH MINAT, PERSEPSI KEBERMANFAATAN, DAN KEMUDAHAN PENGGUNAAN E-FILLING TERHADAP KEPATUHAN WAJIB PAJAK ORANG PRIBADI DI KABUPATEN MANGGARAI
}

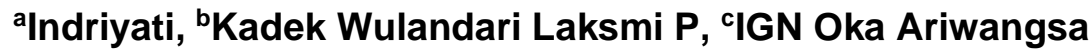 \\ abc Univeristas Pendidikan Nasional Denpasar \\ saungindri@gmail.com
}

\begin{abstract}
ABSTRAK
Pengaruh minat, persepsi kebermanfaatan, dan kemudahan penggunaan EFilling terhadap kepatuhan wajib pajak orang pribadi di Kabupaten Manggarai. Penelitian ini bertujuan untuk mengetahui pengaruh variabel minat, perpsepsi kebermanfaatan, dan kemudahan penggunaan e-filing terhadap kepatuhan wajib pajak orang pribadi di Kabupaten Manggarai. Sampel penelitian yaitu WPOP yang tercatat di KPP Pratama Ruteng Kabupaten Manggarai, yang berjumlah 100 orang. Pengumpulan data dilakukan dengan cara penyebaran kuesioner dengan menggunakan google form. Teknik analisis data terdiri atas uji asumsi klasik, analisis regresi berganda, dan uji hipotesis (uji t). Adapun hasil dari penelitian ini adalah adanya pengaruh positif dan signifikan baik secara parsial maupun simultan antara variabel minat, perpsepsi kebermanfaatan, dan kemudahan penggunaan e-filing terhadap kepatuhan wajib pajak orang pribadi di Kabupaten Manggarai.
\end{abstract}

Kata kunci: Minat, Perpsepsi Kebermanfaatan, Kemudahan Penggunaan e-filling, Kepatuhan Wajib Pajak

\section{ABSTRACT}

This study aims to determine the effect of interest variables, perceived usefulness, and ease of use of e-filing in individual taxpayer compliance in Manggarai Regency. The research sample is WPOP registered at KPP Pratama Ruteng, Manggarai Regency, totaling 100 people. Data was collected by distributing questionaires using google form. The data data analysis technique consisted of classical assumption test, multiple regression analysis, and hypothesis testing (ttest). The results of this study are a positive and significant influence either partially or simultaneously between the variables of interest, perceived usefulness, and ease of use of e-filing in individual taxpayer compliance in Manggarai Regency.

Keywords: Interest, Perceptions of Usefulness, Ease of Use e-filing, Taxpayer Compliance

\section{PENDAHULUAN}

Pembangunan nasional sangat ditopang oleh penerimaan negara salah satunya adalah pajak. Sumber pendapatan negera dari pajak ini, adalah sumber pendapatan negara yang terbesar yang sangat berpengaruh terhadap jalannya pembangunan nasional serta keberlangsungan jalannya roda pemerintahan. Untuk mendukung semua itu, pemerintah menciptakan suatu sistem perpajakan untuk mengelola penerimaan negara serta memanfaatkannya untuk membiayai berbagai aktivitas pembangunan. Di Indonesia sendiri dalam hal sistem pemungutan pajaknya menggunakan self assessment system. Sistem ini memberikan wewenang kepada wajib pajak untuk menghitung, membayar dan melaporkan sendiri pajaknya. Hal ini tentunya berpengaruh terhadap kepatuhan wajib pajak. 
Saat ini sistem perpajakan di Indonesia telah beralih kepada sistem online. Wajib pajak tidak perlu lagi untuk mengantri berlama-lama di kantor pajak untuk melaporkan Surat Pemberitauan (SPT) baik masa maupun tahunan. Tentunya hal ini merupakan suatu terobosan dari Direktorat Jenderal Pajak untuk memberikan kemudahan bagi wajib pajak untuk melakukan kewajiban perpajakannya. Peralihan sistem menjadi sistem online tidak serta merta mendapatkan respon yang baik dari wajib pajak. Wajib pajak juga masih merasa ragu akan pajak yang telah dibayarkan apakah akan merasa sebarannya untuk pembangunan.

E-filing merupakan sistem pelaporan SPT secara online bagi wajib pajak. Walaupun telah lama diterapkan di Indonesia, akan tetapi wajib pajak orang pribadi belum benar-benar fasih dalam penggunaannya. Selain itu akses internet merupakan syarat utama untuk dapat mengakses e-filing tersebut. Seperti daerah-daerah terpencil, dimana akses internet sangat susah untuk didapatkan menyebabkan wajib pajak orang pribadi merasa enggan untuk melaporkan pajaknya. Hal inilah yang menyebabkan tingkat kepatuhan wajib pajak menjadi menurun.

Kabupaten Manggarai wilayah Kabupaten Manggarai merupakan salah satu daerah yang berada di Flores Nusa Tenggara Timur. Hingga saat ini wajib pajak yang memanfaatkan EFilling bisa dikatakan masih tergolong rendah. Berdasarkan tabel 1.1 disebutkan persentase dari tingkat kepatuhan wajib pajak beberapa tahun terakhir di Kantor Pelayanan Pajak (KPP) Pratama Ruteng :

Tabel 1.1

Persentase Tingkat Kepatuhan Pajak

\begin{tabular}{ll}
\hline Tahun & Persentase \\
\hline $\mathbf{2 0 1 6}$ & $65,25 \%$ \\
$\mathbf{2 0 1 7}$ & $85,02 \%$ \\
$\mathbf{2 0 1 8}$ & $81,04 \%$ \\
$\mathbf{2 0 1 9}$ & $67,43 \%$ \\
\hline
\end{tabular}

Sumber: KPP Pratama Ruteng

Berdasarkan tabel 1.1, dapat dilihat persentase tingkat kepatuhan wajib pajak selama beberapa tahun terakhir adalah naik turun. Pada tahun 2016 persentase tingkat kepatuhan wajib pajak adalah 65,25\%. Di tahun 2017 tingkat kepatuhan wajib pajak meningkat menjadi $85,02 \%$. Namun pada 2 tahun berikut nya kepatuhan wajib pajak menurun, yaitu di tahun 2018 menjadi 81,04\%. Dan pada tahun 2019 sebesar $67,43 \%$. Salah satu hal yang menyebabkan tingkat kepatuhan wajib pajak menurun adalah akses internet di kabupaten Manggarai masih terbatas, menyebabkan pengaplikasian e-filing oleh wajib pajak orang pribadi masih sangat kurang. Hal tersebutlah yang menjadi dasar bagi penulis untuk meneliti tentang minat, persepsi kebermanfaatan, kemudahan penggunaan e-filing terhadap kepatuhan wajib pajak orang pribadi di kabupaten Manggarai.

\section{KAJIAN LITERATUR}

\section{Theory of Reasoned Action (TRA)}

Theory Of Reasoned Action merupakan teori yang menjelaskan perilaku manusia, dengan menggunakan asumsi dasar dengan sadar dan mempertimbangkan informasi yang tersedia. Awalnya teori ini diperkenalkan oleh Ajzen dan Flashbein pada tahun 1975. Teori ini menyebutkan bahwa manusia dalam melakukan sesuatu harus memperoleh informasi terlebih dahulu. Informasi yang valid dan lengkap akan mempengaruhi sikap seseorang dan pengambilan keputusan apa yang akan dilakukan. Terkait dengan kepatuhan wajib pajak orang pribadi, maka wajib pajak tersebut harus mendapatkan informasi yang jelas tentang pengaplikasian e-filing. Baik informasi tersebut didapat dari web maupun sosialisasi secara langsung dari kantor pajak. Adapun konsep yang digunakan dalam teori ini adalah konsep 
kompatibilitas dan konsep intensi perilaku. Teori ini merupakan model penelitian umum yang baik yang dapat diaplikasikan dalam memprediksi dan menjelaskan perilaku.

\section{Kepatuhan Wajib Pajak}

Menurut Peraturan Menteri Keuangan Nomor 192/PMK.03/2007 tentang Wajib Pajak dengan Kriteria Tertentu dalam Rangka Pengembalian Pendahuluan Kelebihan Pembayaran Pajak, Wajib Pajak dengan kriteria tertentu yang selanjutnya disebut sebagai Wajib Pajak Patuh adalah Wajib Pajak yang memenuhi persyaratan sebagai berikut :

Tepat waktu dalam menyampaikan Surat Pemberitahuan; Tidak mempunyai tunggakan pajak untuk semua jenis pajak, kecuali tunggakan pajak yang telah memperoleh izin mengangsur atau menunda pembayaran pajak; Laporan keuangan diaudit oleh Akuntan Publik atau lembaga pengawas keuangan pemerintah dengan pendapat Wajar Tanpa Pengecualian selama 3 (tiga) tahun berturut-turut; dan Tidak pernah dipidana karena melakukan tindak pidana dibidang perpajakan berdasarkan putusan pengadilan yang telah mempunyai kekuatan hukum tetap dalam jangka waktu lima (5) tahun terakhir).

Dasar hukum ini mengatur tentang kriteria dari kepatuhan wajib pajak. Dimana wajib pajak dapat dikatakan patuh jika telah melakukan pelaporan SPT, baik itu SPT tahunan maupun SPT masa. Bagi wajib pajak yang telah melaporkan SPTnya pastinya telah melakukan pembayaran pajak sesuai dengan Undang-Undang yang berlaku.

\section{Minat penggunaan e-filing}

Ketertarikan dalam melakukan seuatu berkaitan erat dengan minat individu itu sendiri. Niat adalah faktor pendorong utama seorang individu untuk melakukan sesuatu. Berhasil atau tidaknya perilaku tersebut ditentukan dari besarnya niat individu tersebut. Disamping itu adapun indikator-indikator yang menentukan individu untuk tertarik menggunakan sistem adalah : 1) Kemauan untuk menggunakan; 2) mencoba untuk menggunakan; 3) kontinyuitas di masa mendatang (Winayu : 2013). Melihat dari penelitian yang dilakukan oleh Setyana (2017) diperoleh hasil bahwa minat penggunaan e-filing berpengaruh positif terhadap kepatuhan wajib pajak.

$\mathrm{H} 1$ = Minat penggunaan E-Filing berpengaruh terhadap kepatuhan wajib pajak orang pribadi

\section{Persepsi Kebermanfaatan e-filing}

Menurut Perkasa (2016) menyebutkan bahwa pandangan terhadap manfaat sistem berkaitan dengan bagaimana sistem tersebut dapat meningkatkan kinerja individu yang menggunakan sistem tersebut baik dari sisi produktivitas maupun efektivitas sistem. Dalam konteks penerapan e-Filing pada penelitian ini, pandangan terhadap manfaat e-filing adalah bagaimana wajib pajak merasa bahwa sistem ini sangat bermanfaat dalam pelaporan SPT. E-filing dipandang sangat membantu wajib pajak dalam memenuhi kewajiban dari wajib pajak. Purwiyanti dan Laksito (2020) menemukan hasil bahwa adanya hubungan yang signifikan antara variabel persepso kebermanfaatan dengan kepatuhan wajib pajak. Berdasarkan uraian tersebut maka dapat dirumuskan hipotesis sebagai berikut :

H2 : Persepsi kerbermanfaatan e-filing bepengaruh terhadap kepatuhan wajib pajak orang pribadi.

\section{Kemudahan Penggunaan e-filing}

Kemudahan aplikasi e-filing berkaitan dengan bagaimana wajib pajak dapat dengan mudah menggunakanan sistem tersebut. Sistem yang baik tentunya dapat memudahkan pengguna dalam mengoperasikannya. Mudah dapat berarti bahwa tidak memerlukan usaha yang lebih untuk melakukannya. Tjini dan Baridwan (2012) menyebutkan bahwa persepsi kemudahan adalah seseorang itu percaya suatu teknologi dapat dengan mudah untuk digunakan dan dipahami. Penelitian yang dilakukan oleh Firdaus (2019), diperoleh hasil bahwa mayoritas wajib pajak menggunakan e-filing terhadap kepatuhan wajib pajak. Hal ini disebabkan karena e-filing disesuaikan dengan kebutuhan wajib pajak serta fleksibel dapat dengan mudah digunakan. Berdasarkan uraian tersebut maka dapat dirumuskan hipotesis sebagai berikut : 
H3 : Kemudahan penggunaan e-filing berpengaruh terhadap kepatuhan wajib pajak orang pribadi

\section{e-filing}

Peraturan Direktur Jendral Pajak Nomor PER-06/PJ./2014 e-filling adalah cara pelaporan SPT Tahunan secara elektronik yang dilakukan secara on-line dan realtime melalui internet pada website DJP. Penggunaan e-filing dapat meminimalisir dalam segi biaya, berkurangnya penggunaan kertas, amplop, perangko, serta data akan langsung dikirim ke database Direktoral Jenderal Pajak melalui internet.

Kerangka pemikiran pada penelitian ini yaitu:

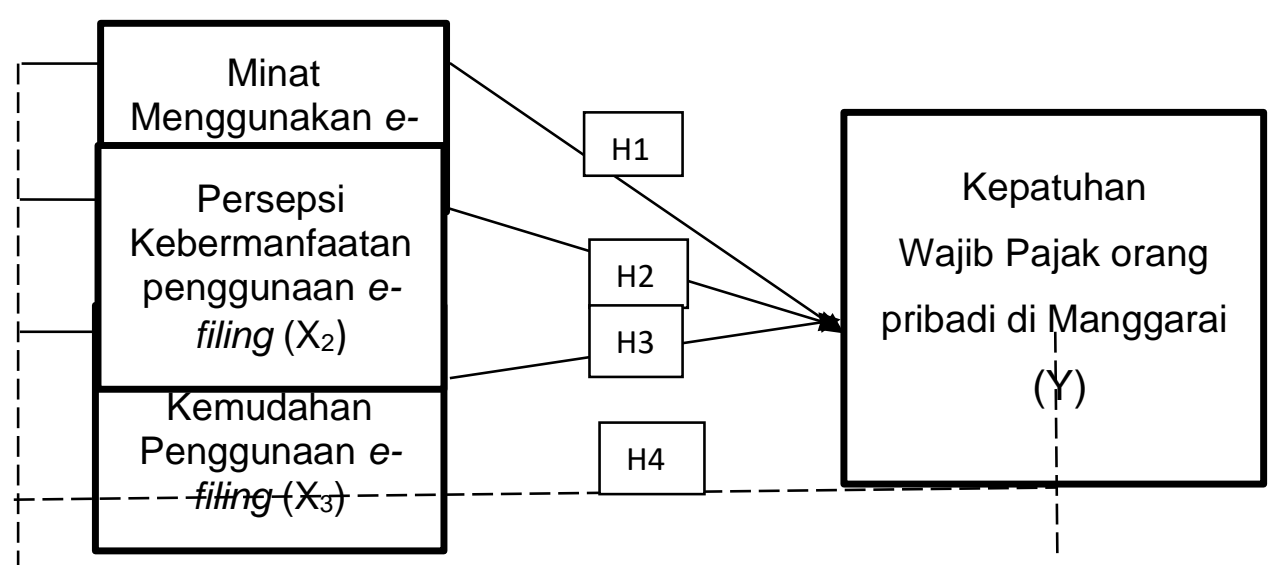

\section{METODE PENELITIAN}

Penelitian ini dilakukan pada Kantor Pelayanan Pajak (KPP) Pratama Ruteng, Kab. Manggarai. KPP Pratama Ruteng berlokasi di Jln. Yos Sudarso No. 26, Mbaumuku, Langke Rembong, Kabupaten Manggarai, Nusa Tenggara Timur. Populasi dalam penelitian ini adalajh WP OP yang terdaftar di KPP Pratama Ruteng kabupaten Manggarai, yaitu sebanyak 24.119 orang. Penentuan sampel dalam penelitain ini menggunakan rumus Slovin (Sugiyono : 2018). Adapun perhitungan sampel dengan cara sebagai berikut :

$$
n=\frac{N}{(1+N e 2)}
$$

Keterangan :

$\mathrm{n}=$ Besaran sampel

$\mathrm{N}=$ besaran populasi

$\mathrm{e}=$ nilai kritis (batas ketelitian) yang diinginkan (persen kelonggaran). Dalam penelitian ini menggunakan persentase kelonggaran $10 \%$.

Perhitungan sampel :

$$
n=\frac{24.119}{1+24.119(0,1)^{2}}
$$


Teknik analisis data dalam penelitian terdiri atas uji validitas, uji reliabilitas, uji multikolinearitas, uji heteroskedastisitas, uji normalitas, analisis regresi linier berganda, koefisien determinasi, uji $\mathrm{F}$ dan uji t.

\section{ANALISIS DATA DAN PEMBAHASAN}

Berikut disajikan hasil pengujian instrument :

\section{Uji validitas}

Dari tabel diketahui bahwa instrumen-instrumen disetiap variabel adalah valid dan dapat dipakai untuk menguiji hipotesis penelitian, karena nilai disetiap instrumen memilliki nilai korelasi di atas 0,3.

\section{Uji Reliabilitas}

Berdasarkan hasil uji diketahui bahwa seluruh instrumen reliabel, karena nilai croonbach's alpha masing-masing instrumen lebih besar dari 0,60 sehingga dapat dipakai untuk melakukan penelitian atau menguji hipotesis penelitian.

\section{Uji Normalitas}

Pengujian normalitas dalam pengujian menggunakan uji model regresi untuk mengetahui data yang digunakan berdistribusi normal atau tidak, dan data dikatakan bersifat normalitas karena nilai signifikan $>0,05$.

\section{Uji Multikolinieritas}

Berdasarkan hasil analisis multikolinearitas, menunjukkan bahwa nilai Tolerance $>0,1$ dan niilai VIF < 10. Jadi dapat disimpulkan bahwa tidak ada multikolinieritas antara variabel bebas dallam model regresi ini.

\section{Uji Heterokedastisitas}

Berdasarkan gambar scatter plot diketahui sebaran plot data untuk regresi terlihat menyebar secara acak, sebaran data tidak mengumpul di satu sudut/bagian maka disimpulkan tidak terjadi heterokedastisitas, sehingga dapat dikatakan data adalah homogen.

\section{Analisis Determinasi}

Berdasarkan hasil analisis regrresi berganda diketahui nilai koefesien determinasi (D) sebesar $0,821 \times 100 \%=82,10 \%$. Dengan demikian disimpulkan Pengaruh Minat Penggunaan (X1), Persepsi Kebermanfaatan (X2), dan Kemudahan Penggunaan E-Filling (X3) Terhadap Kepatuhan Wajib Pajak Orang Pribadi (Y) di Kabupaten Manggarai adalah sebesar $82,10 \%$. Sedangkan sisanya sebesar $17,90 \%$ dipengaruhi oleh faktor lain yang tidak dibahas pada penelitian ini.

\section{(Uji-F)}

Dari hasil perhitungan diperoleh F-hitung sebesar 152,807 dengan tingkat signifikansi $0,000<$ nilai $(\alpha) 5 \%(0,05)$ yang berarti secara simultan ada pengaruh positif antara Pengaruh Minat Penggunaan (X1), Persepsi Kebermanfaatan (X2) dan Kemudahan Penggunaan EFiling (X3) terhadap Kepatuhan Wajib Pajak Orang Pribadi (Y) di Kabupaten Manggarai.

\section{(Uji-t)}

Selanjutnya tahapan-tahapan analisis secara parsial masing-masing variabel dengan menggunakan uji t adalah :

Pengaruh Minat Penggunaan (X1) Terhadap Kepatuhan Wajib Pajak Orang Pribadi (Y) di Kabupaten Manggarai.

Berdasarkan hasil perhitungan untuk Pengaruh variabel Minat Penggunaan (X1) diperoleh t-hitung sebesar 2,347 dengan tingkat signifikansi $0,021<$ nilai $(\alpha) 5 \%(0,05)$ ini 
berarti secara parsial ada pengaruh positif antara Minat Penggunaan e-filing (X1) Terhadap Kepatuhan Wajib Pajak Orang Pribadi (Y) di Kabupaten Manggarai. Hal ini berarti bahwa semakin tinggi minat penggunaan e-filing maka semakin tinggi tingkat kepatuhan wajib pajak orang pribadi di kabupaten Manggarai.

Menguji Pengaruh Persepsi Kebermanfaatan (X2) Terhadap Kepatuhan Wajib Pajak Orang Pribadi (Y) di Kabupaten Manggarai .

Berdasarkan hasil perhitungan untuk Pengaruh variabel Persepsi Kebermanfaatan (X2), diperoleh t-hitung sebesar 0,969 dengan tingkat signifikansi 0,335 < nilai (a) $5 \%(0,05)$, Ini berarti secara parsial ada Pengaruh positif antara variabel Persepsi Kebermanfaatan (X2) Terhadap Kepattuhan Wajib Pajak Orang Pribadi (Y) di Kabupaten Manggarai.

Menguji Pengaruh Kemudahan Penggunaan E-Filling (X3) Terhadap Kepatuhan Wajib Pajak Orang Pribadi $(\mathrm{Y})$ di Kabupaten Manggarai Berdasarkan hasil perhitungan untuk Pengaruh variabel Kemudahan Penggunaan E-Filing (X3), diperoleh t-hitung sebesar 6,604 dengan tingkat signifikansi $0.000<$ nilai $(\alpha) 5 \%(0,05)$, Ini berarti secara parsial memiliki Pengaruh positif antara variabel Kemudahan Penggunaan E-Filing (X3), Terhadap Kepatuhan Wajib Pajak Orang Pribadi (Y) di Kabupaten Manggarai.

\section{Pembahasan}

1) Pengaruh minat menggunakan E-Filing Terhadap Kepatuhan Wajib Pajak Orang Pribadi di Manggarai

Berdasarkan hasil perhitungan untuk variabel Minat Penggunaan (X1) diperoleh thitung sebesar 2,347 dengan tingkat signifikansi 0,021 < nilai $(\alpha) 5 \%(0,05)$ ini berarti secara parsial berpengaruh positif antara Minat Penggunaan (X1) Terhadap Kepatuhan Wajib Pajak Orang Pribadi $(\mathrm{Y})$ di Kabupaten Manggarai, sehingga dari uraian diatas, maka rumusan hipotesis pertama sebagai berikut $\mathrm{H} 1$ : Minat mennggunakan e-filing berpengaruh positif terhadap kepatuhan Wajib Pajak Orang Pribadi di Manggarai dapat diterima. Berdasarkan Theory of Reasoned Action, semakin memahami individu tersebut tentang penggunaan efiling maka akan meningkatkan minat penggunaan e-filing tersebut. Tanpa adanya informasi yang jelas dan lengkap tentang e-filing tentu saja individu tidak akan tahu dan pastinya tidak akan tertarik untuk menggunakan e-filing tersebut. Hasil penelitian ini sejalan dengan hasil penelitian dari Setyana (2017) yang menemukan bahwa minat menggunakan e-filing berpengaruh signifikan terhadap tingkat kepatuhan wajib pajak orang pribadi di Magelang.

2) Pengaruh Persepsi Kebermanfaatan Penggunaan E-Filing terhadap Kepatuhan Wajib Pajak Orang Pribadi di Manggarai.

Berdasarkan hasil perhitungan untuk Pengaruh variabel Persepsi Kebermanfaatan (X2), diperoleh t-hitung sebesar 0,969 dengan tingkat signifikansi 0,335 < nillai $(\alpha) 5 \%(0,05)$, Ini berarti secara parsial memiliki Pengaruh positif antara variabel Persepsi Kebermanfaatan (X2) Terhadap Kepatuhan Wajib Pajak Orang Pribadi (Y) di Kabupaten Manggarai, sehingga dari uraian diatas, maka rumusan hipotesis kedua adalah sebagai berikut $\mathrm{H} 2=$ Persepsi Kebermanfatan Penggunaan E-Filing berpengaruh positif terhadap Kepatuhan WP OP di Manggarai dapat diterima. Hal ini berarti bahwa semakin baik persepsi kebermanfaatan penggunaan e-filing maka semakin meningkat tingkat kepatuhan wajib pajak orang pribadi di kabupaten Manggarai. Pandangan individu terhadap suatu sistem informasi menyebabkan mereka memiliki keyakinan bahwa sistem tersebut dapat memberikan manfaat dan memberikan keuntungan bagi mereka baik dari segi waktu maupun biaya. Wajib pajak tidak perlu lagi mengantri di kantor pajak untuk melaporkan SPT tahunannya dikarenakan pelaporan sudah dapat dilakukan dimana saja karena pelaporan sudah secara online. Dengan adanya pemanfaatan e-filing ini tentu saja memudahkan wajib pajak untuk melakukan kewajiban perpajakannya. Hasil penelitian ini sejalan dengan hasil penelitian Purwiyanti \& Laksito (2020) yang menemukan bahwa persepsi kebermanfaatan berpengaruh signifikan terhadap kepatuhan wajib pajak. Begitu pula dengan hasil penelitian Firdaus dan Pratolo (2020) memperoleh hasil variabel kemanfaatan e-filing berpengaruh signifikan terhadap kepatuhan wajib pajak. 
3) Pengaruh Persepsi Kemudahan Penggunaan E-Filing terhadap

Kepatuhan

Wajib Pajak Orang Pribadi di Manggarai.

Berdasarkan hasil perhitungan untuk Pengaruh variabel Kemudahan Penggunaan EFiling (X3), diperoleh t-hitung sebesar 6,604 dengan tingkat signifikansi $0.000<$ nillai $(\alpha) 5 \%$ $(0,05)$, Ini berarti secara parsial memiliki pengaruh positif antara variabel Kemudahan Penggunaan E-Filing (X3), Terhadap Kepatuhan Wajib Pajak Orang Priibadi (Y) di Kabupaten Manggarai, sehingga dari uraian diatas, maka rumusan hipotesis ketiga adalah sebagai berikut H3 = Persepsi Kemudahan Penggunaan E-Filing berpengaruh positif terhadap Kepatuhan WP OP di Manggarai dapat diterima. Hal ini berarti bahwa semakin baik perpsepsi kemudahan penggunaan e-filing maka semakin meningkat kepatuhan wajib pajak. Semakin baik suatu sistem, maka akan semakin mudah untuk dipahami dan digunakan. Dalam hal ini Dirjen Pajak secara terus menerus memperbaiki sistem agar menjadi lebih baik sehingga wajib pajak dapat dengan mudah untuk menggunakannya. Dengan kemudahan yang didapatkan tentu saja wajib pajak akan lebih tertarik untuk menggunakan sistem tersebut. Hasil penelitian ini sejalan dengan hasil penelitian dari Firdaus (2020) yang menemukan bahwa mayoritas wajib pajak menggunakan e-filing karena sesuai dengan kebutuhan wajib pajak dan fleksibel serta mudah dalam pengoperasiannya. Begitu pula dengan hasil penelitian Natalia, et al (2019) menemukan persepsi kegunaan berpengaruh signifikan terhadap penggunaan e-filing.

4) Pengaruh Minat, Persepsi Kebermanfaatan, dan Kemudahan Penggunaan E-Filing terhadap Kepatuhan Wajib Pajak Orang Pribadi di Manggarai.

Berdasarkan hasil perhitungan diperoleh F-hitung sebesar 152,807 dengan tiingkat signifikansi $0,000<$ nilai $(\alpha) 5 \%(0,05)$. Ini berarti secarra simultan ada pengaruh positif anttara Pengaruh Minat Penggunaan (X1), Persepsi Kebermanfaatan (X2) dan Kemudahan Penggunaan E-Filling (X3) Terhadap Kepatuhan Wajiib Pajak Orang Priibadi (Y) di Kabupaten Manggarai. Sehingga dari uraian diatas maka rumusan hipotesis ke empat adalah sebagai berikut $\mathrm{H} 4=$ Minat menggunakan e-fiiling, persepsi kebermanfaattan dan persepsi kemudahan pengguunaan e-filing berpengaruh positif terhadap kepatuhan WP OP di Manggarai dapat diterima.

\section{SIMPULAN}

Secara parsial ada pengaruh positif antara Minat Penggunaan (X1) Terhadap Kepatuhan Wajib Pajak Orang Priibadi (Y) di Kabupaten Manggarai, karena Pengaruh variabel Minat Penggunaan (X1) diperoleh t-hitung sebesar 2,347 dengan tingkat signifikansi $0,021<$ niliai (a) $5 \%(0,05)$.

Secara parsial memilliki Pengaruh positif antara variabel Persepsi Kebermanfaatan (X2) Terhadap Kepatuhan WP OP (Y) di Kabupaten Manggarai, karena Pengaruh variabel Persepsi Kebermanfaatan (X2), diperoleh t-hittung sebesar 0,969 dengan tingkat signifikansi $0,335<$ nilai $(\alpha) 5 \%(0,05)$,

Secara parsial memiliki Pengaruh positif antara variabel Kemudahan Penggunaan E-Filling (X3), Terhadap Kepatuhan Wajiib Pajak Orang Pribadi (Y) dii Kabupaten Manggarai, karena Pengaruh variabel Kemudahan Penggunaan E-Filling (X3), diperoleh t-hitung sebesar 6,604 dengan tingkat signifikansi $0.000<$ nilai $(\alpha) 5 \%(0,05)$.

\section{Saran}

Sebaiknya pemerintah lebih gencar dalam memberikan sosialisasi tentang kebermanfaatan dan tata cara penggunaan e-filling kepada masyarakat agar wajib pajak mau menggunakan e-filling dalam pelaporan SPT, sehingga dapat meningkat pula kepatuhan wajib pajak di kabupaten Manggarai.

Kepada peneliti selanjutnya untuk dapat mengembangkan dan mendalami faktorfaktor lain yang dapat meningkatkan Kepatuhan Wajib Pajak Orang Pribadi di Kabupaten Manggarai. 


\section{DAFTAR PUSTAKA}

Andrian, Agus Dkk 2014, Analisis Pengaruh Persepsi Kegunaan, Persepsi Kemudahan dan Sikap Penggunaan Terhadap Minat Perilaku Penggunan Billing System (Studi PAda Wajb Pajak Di Kantor Pelayanan Pajak Pratama Malang Utara. Universitas Brawijaya, Malang.

Astina, I Putu Surya dan Putu Ery Setiawan. 2018, Pengaruh Pemahaman Peraturan Perpajakan, Kualitas Pelayanan Fiskus dan Kesadaran Wajib Pajak Terhadap Tingkat Kepatuhan WPOP. E-Jurnal Akuntansi Universitas Udayana Vol.23.1 April (2018): 1-30. "Buku Panduan Hak dan Kewajiban Wajib Pajak." Diambil dari : http://www.perpustakaan.kemenkeu.go.id/FOLDEREBOOK/HKWP\%20L engkap.pdf pada 7 Sepember 2020.

Damin, 2008, Ketentuan Umum dan Tata Cara Perpajakan, Direktorat Jenderal Pajak Devano dalam Supadmi, 2012, Perpajakan: Kolnsep, Teori dan Isu, Kencana, Jakarta. Eprints "Bab III Metode Penelitian ." Artikel. Diunduh dari http://repository.unpas.ac.id/30085/7/7.\%20BAB\%20III.pdf pada hari Jumat 4

September 2020

Irmadhani, dan Mahendra Adhi Nugroho, 2010, Pengaruh Persepsi Kebermanfaatan, Persepsi Kemudahan Penggunaan dan Computer Self Efficacy, Terhadap Penggunaan Online Banking Pada Mahasiswa S1 Fakultas Ekonomi Universitas Negeri Yogyakarta.

Iriniangsih, 2015, Pengaruh Kesadaran Wajib Pajak, Pelayanan Fiskus Dan Sanksi Administrasi Pajak Terhadap Kepatuhan Wajib Pajak Dalam Membayar Pajak Kendaraan Bermotor di Kantor Bersama SAMSAT Sleman. Skripisi Universitas PGRI Yogyakarta.

Kanuk (2014), Akuntansi Perpajakan. Jakarta: PT Grasindo

Kartini, D.A., Suhadak, dan Azizah, D.F., 2015, Pengaruh Persepsi dan Perilaku Wajib

Pajak atas Penerapan E-Filling terhadap Kepatuhan Wajib Pajak Orang Pribadi, skripsi .Prpogram Studi Administrasi bisnis Universitas Brawijaya.

Kusuma, K. C. 2016. Pengaruh Kualitas Pelayanan Pajak, Pemahaman Peraturan

Perpajakan Serta Sanksi Perpajakan Terhadap Kepatuhan Wajib Pajak Orang Pribadi Dalam Membayar Pajak tahun 2014. Skripsi. Prodi Akuntansi Universitas Negeri Yogyakarta.

Mardiasmo, 2015, Perpajakan, Andi Offset, Yogyakarta.

Nurmantu, 2013, Pengantar Perpajakan. Jakarta: Kelompok Yayasan Obor

Nal, B. (2019) KPP Pratama Ruteng ajak Wajib Pajak Segera Manfaatkan E- Filling.

Diambil dari http://www.beritaflores.com/2019/03/06/kkpp- pratama- ruteng-ajak-wajibpajak-segera-manfaatkan-e-filling pada tanggal 2 September 2020

Pradana, Rieza Adhitya. 2019. Pengaruh Pemahaman Perpajakan, Penerapan E-System Perpajakan, dan Pemeriksaan Pajak Terhadap Tingkat Kepatuhan Wajib Pajak Orang Pribadi Dalam Membayar Pajak Pada Kantor Pekayanan Pajak (KPP) Pratama Singaraja. JIMAT (Jurnal IImiah Mahasiswa Akuntansi) Undiksha, 7(1).

Samadiartha,I D.N, dan Sri, G.D, 2017, Dampak Sistem E-Filling, Pengetahuan Perpajakan, Sosialisasi Perpajakan, Kesadaran Wajib Pajak terhadap Kepatuhan Wajib Pajak, Jurnal.Pogram Studi Manajemen UNDIKNAS Denpasar.

Suandi, 2008, Perpajakan. Penerbit: Salemba Empat Jakarta. 